\title{
A COMPREHENCIVE OVERVIEW ON UTILIZATION OF OZONE IN FOOD PROCESSING
}

\section{SRINATH.D \& SWAROOPA.G}

Professor Department of Foods \& Nutrition, Post Graduate and Research Centre, Jayashankar Telangana State

Agricultural University, Hyderabad, Telangana, India

\begin{abstract}
Ozone $\left(\mathrm{O}_{3}\right)$ is a potent antimicrobial agent due to its strong oxidizing potential; it has wide application in the food industry. Ozone is one of the most powerful known Sanitizers. Ozone is formed from three oxygen atoms. Ozone is commonly used for the treatment of water in municipal and industrial applications. The special advantage of ozone is in the environmentally friendly way in which it works. Harmful substances, colours, odours and microorganisms are destroyed directly by oxidation, without the formation of harmful chlorinated by-products. However, some negative effects of ozonation are the undesirable changes that may occur in food quality, such as, a loss of phenolic compounds and ascorbic acid, inactivation of some enzymes and changes in color.

KEYWORDS: Ozone, Oxidation, Inactivation, Treatment \& Decomposition
\end{abstract}

Received: Jul 17, 2017; Accepted: Aug 05, 2017; Published: Aug 28, 2017; Paper Id.: IJASROCT20176

\section{INTRODUCTION}

Ozone is a strong oxidant and potent disinfecting agent (Zeynep, et al., 2004). Ozone exists in the gaseous state at room and refrigeration temperature and it is partially soluble in water. At room temperature, ozone is an unstable gas. Ozone readily degrades but has a longer half-life in the gaseous state than in aqueous solution (Rice, 1986). Ozone is relatively stable in air but highly unstable in water, decomposes in a very short time. It cannot be stored and must be generated continuously.

A protective layer of ozone is presently 6 to 30 miles above the earth's surface at a concentration of approximately $10 \mathrm{ppm}$ (parts per million). This ozone layer helps protect the earth's surface from harmful ultraviolet radiation.

Ozone is formed in the stratosphere, in photochemical smog and by UV sterilization lamps, high voltage electric arcs, and gamma radiation plants (Mustafa, 1990).

\section{Acceptance of Ozone Utilization}

A petition submitted in August 2000 to the Food and Drug Administration (FDA) for approval of ozone as a direct food additive for the treatment, storage, and processing of foods in gas and aqueous phases has been accepted later (Federal Register 2001).

The United States Food and Drug Administration (FDA) has recognized, since 2001, that $\mathrm{O}_{3}$ is GRAS (Generally Recognized as Safe) for the treatment, storage and processing of food and water (FDA, 2001). 
Ozone is a powerful sanitizer that may meet the expectations of the industry, the approval of the regulatory agencies and acceptance of the consumer (Khadreet al., 2001). But it is better to use in permissible limits. So World Health Organization (WHO) recommends $0.1 \mathrm{mg} / \mathrm{m}^{3}$ for an 8-hour mean (WHO, 2006). Excess ozone auto-decomposes rapidly to produce oxygen, and thus it leaves no residues in food (Shigezo and Hirofumi, 2006).

\section{Production of Ozone}

Ozone can be generated on-site as required by several techniques, three of which are available commercially at the present time - corona discharge, UV radiation and electrolysis. In order to generate ozone, a diatomic oxygen molecule must first be split. The resulting free radical oxygen is thereby free to react with another diatomic oxygen to form the triatomic ozone molecule. However, in order to break the $\mathrm{O}-\mathrm{O}$ bond a great deal of energy is required.

The established technology for generating ozone is by corona discharge of dry air or oxygen. There are other methods (UV irradiation of oxygen at 140-190 NM; electrolysis) but these have yet to find widespread application in water treatment.

The corona discharge method can obtain high concentrations of $\mathrm{O}_{3}$ at a low cost; however, UV radiation can also be used for commercial production of $\mathrm{O}_{3}$ but with a lower concentration and yield (Tapp and Rice, 2012).

Ozonizers expose $\mathrm{O}_{2}$ molecules to a high voltage electrical discharge which initiates the formation of free radical oxygen and thereby generates $\mathrm{O}_{3}$ (WCBBC, 2006).

Ultraviolet radiation (188nm wavelength) and corona discharge methods can be used to initiate free radical oxygen formation and, thereby generate ozone (Rice et al. 1981).

The use of oxygen enables ozone to be generated at higher concentrations, which is more energy efficient and beneficial for mass transfer, but carries the additional cost of the oxygen. There are some air-fed installations which have the facility to enrich the feed gas with oxygen, which may be justified where there are infrequent short-term peak ozone demands (Langlaiset al, 1991).

\section{Properties of Ozone}

Ozone has the strongest oxidization effect after fluorine, and this property has been used in sterilization for food and processing plants. Moreover, there is no fear of toxic residues as with chlorine-based sterilizers and no hazardous trihalomethanes are formed. Based on these advantages, ozone has been used in water and air treatment for food products, food materials and food processing plants (Shigezo and Hirofumi 2006).

Ozone is a blue gas at ordinary temperature, but at concentrations at which it is normally produced the color is not noticeable. At $-112^{\circ} \mathrm{C}$, ozone condenses to a dark blue liquid (Oehlschlaeger, 1978). Ozone has a longer half-life in the gaseous state than in aqueous solution (Rice, 1986).

The efficacy of ozone treatment is affected by $\mathrm{pH}$, temperature, relative humidity, concentration, and phase of microbial growth and by the presence of organic material (Sofos and Busta, 1991). Ozone solubility in water is 13 times that of oxygen at $0-30^{\circ} \mathrm{C}$ and it is progressively more soluble in colder water (Rice, 1986). The presence of minerals in the water may also catalyze ozone decomposition (Hoigné and Bader 1985). Therefore, solubility of ozone increases when purity of water increases. 


\section{Applications of Ozone}

Ozone is a powerful antimicrobial substance due to its potential oxidizing capacity. Ozone use may have many advantages in the food industry. Ozone has been used by industry for many years and in many different types of applications such as odor control, water purification, and as a disinfectant (Mork, 1993). Research has found that ozone levels of less than 9 ppm are necessary for sick buildings or profession disinfection (Khurana, 2003). The issue of safety must always be addressed when using ozone technology for use indoors with human exposure. A study by Boeniger (1995), found that ozone air cleaners are a potential health risk if used at high levels indoors.

The treatment of wheat flour with gaseous ozone inhibited microbial growth in namamen products and increased their storage life (Naitohet al., 1989).

Ozonated water is easier to handle than ozone gas (Shigezo and Hirofumi, 2006). Ozonated water is one of the most effective Sanitizers known in vegetables and fruits, yet it leaves no hazardous residues on vegetables and fruits or above, contact surfaces (Shigezo and Hirofumi, 2006). Ozonated water containing $0.5-5.0 \mathrm{mg} / \mathrm{L}$ available ozone with abundant volume was effective as a disinfectant for fresh vegetables and fruits without causing discoloration (Naitoh, 1991).

Ozone application for fresh fish helps suppress the characteristic smell which sometimes can be disagreeable, hence giving a healthful aspect of the fish (Goncalves, 2009).

Aqueous ozone was also used to treat packaging and food contact materials (Khadre and Yousef, 2001). Five-log reduction was observed in the bacterial count of plastic films treated with ozonated water (Khadre and Yousef, 1999). Combinations of ozone with other oxidants such as hydrogen peroxide were also used to sanitize packaging films (Gardner and Sharma, 1998).

Ozone is known to react with natural organic matter (NOM) and may produce a range of by-products include aldehydes, ketones and Quinones (Langlaiset al, 1991). Complete mineralization of organic material with ozone does not usually occur to any great extent under drinking water disinfection conditions. Regulated halogenated organic by-products such as trihalomethanes (THMs) are not formed by ozonation (Langlaiset al, 1991), and ozonation can have the additional benefit of reducing the overall THM formation arising from chlorine dosing downstream.

Sykes (1965) reported that chlorine selectively destroyed certain enzymes, whereas ozone acted as a general protoplasmic oxidant. Inactivation of enzymes by ozone is probably due to the oxidation of sulfhydryl groups in cysteine residues (Chang 1971).

Restaino and others (1995) studied a group of food-related microorganisms, observed that the gram-negative bacteria were substantially more sensitive to ozone in pure water than the gram-positive ones. Relatively low concentrations of ozone and short contact time are sufficient to inactivate bacteria, molds, yeasts, parasites and viruses (Kim et al., 1999).

\section{LIMITATIONS}

Ozone is a toxic, bluish, unstable, potentially explosive gas and is a hazard to plants and animals (Braker and Mossman, 1980). Oehlschlaeger, (1978) reported that the liquid ozone is easily exploded if greater than $20 \%$ ozone to oxygen mixtures occur. Explosions may be detonated by electrical sparks or by sudden changes in temperature or pressure. 
However, in practical usage explosions of ozone are extremely rare.

$\mathrm{O}_{3}$ can also cause negative alterations, such as oxidation of lipids, changes in sensory characteristics, color loss, degradation of phenolic compounds and some vitamins, among other adverse effects (Patilet al., 2010; Gabler et al., 2010).

As $\mathrm{O}_{3}$ is a toxic gas, levels higher than the permissible limits may cause undesirable physiological effects on the central nervous system, heart, and vision (PubChem, 2015). In humans, ozone primarily affects the respiratory tract. Symptoms of ozone toxicity include headache, dizziness, a burning sensation in the eyes and throat, a sharp taste and smell, and cough. Chronic toxicity symptoms might cause headache, weakness, decreased memory, increased prevalence of bronchitis and increased muscular excitability (Hoof, 1982).

\section{SUMMARY AND CONCLUSIONS}

Ozone is a powerful antimicrobial agent. Reacts faster than chlorine with many organic materials and produces fewer decomposition products. Ozone as an oxidant is used in water treatment, sanitizing, washing and disinfection of equipment, odour removal, and fruit, vegetable, meat and seafood processing. The most common uses of ozone for food treatment are preserved, disinfection and to increase the ripening time of fruits and vegetables, etc. Ozone targets intracellular enzymes and cell components of foods or on microorganisms. Ozone $\left(\mathrm{O}_{3}\right)$ is effective against the majority of microorganisms tested and its applications in the food industry are related to decontamination of product surface and water treatment. However, still so much research work to be done to overcome the limitations and to improve the efficacy of ozone.

\section{REFERENCES}

1. Boeniger, M. F. (1995). Use of ozone generating devices to improve indoor air quality. American Industrial Hygiene Association Journal, 56(6), 590-598.

2. Braker W and Mossman, AL (1980). Matheson Gas Data Book, Matheson Gas Products, Secaucus, NJ07094, USA.

3. Chang SL. 1971. Modern concept of disinfection. J Sanitation EngDiv 97:689-707.

4. FDA. Food and Drug Administration. 2001. Secondary Direct Food Additives Permitted in Food for Human Consumption. Federal Register 66(123): 33829-33830.

5. Federal Register, 2001. Secondary direct food additives permitted in food for human consumption. Federal Register 66(123):33829-33830.

6. Gabler, F. M., Smilanick, J. L., Mansour, M. F. and Karaca, H. 2010. Influence of fumigation with high concentrations of ozone gas on postharvest gray mold and fungicide residues on table grapes. Postharvest Biology and Technology 55(2): 8590.

7. Gardner DWM, Sharma G. 1998. The kinetics of Bacillus subtilisspore inactivation on filter paper by ultraviolet light and ultraviolet light in combination with hydrogen peroxide. J ApplMicrobiol, 84:633- 641.

8. Gonçalves AA (2009). Ozone-An Emerging Technology for the Seafood Industry. Brazilian Archives of Biology and Technology, 52(6): 1527-1539.

9. Hoigné J, Bader H. 1985. Rate constants of reactions of ozone with organic and inorganic compounds in water. III: Inorganic compounds and radicals. Water Res 19:993.

10. Hoof, F. V. (1982). Professional risks associated with ozone. In W. J. Masschelein (Ed.), Ozonation manual for water and 
waste water treatment (pp. 200-201). New York: Wiley-Interscience.

11. Khadre MA and Yousef AE (1999). Usability of Ozone for Decontamination of Food-Contact Surfaces of plastic Packaging Materials', Presented at Ann Mtgof Inst of Food Technologists, Chicago, IL.

12. Khadre MA and Yousef AE (2001). Decontamination of a multilaminated aseptic food packaging material and stainless steel by ozone. Journal of Food Safety, 21(1): 1-13.

13. Khadre MA, Yousef AE and Kim JG (2001). Microbiological aspects of ozone application in food: A Review. Journal of Food Science, 66(9): 1242-1252.

14. Khurana, A., Chynoweth, D. P., \& Teixeira (2003). Ozone treatment for prevention of microbial growth in air conditioning systems. Masters theses, University of Florida.

15. Kim JG, Yousef AE and Dave S (1999). Application of ozone for enhancing the microbiological safety and quality of foods: a review. Journal of Food Protections, 62(9): 1071-1087.

16. Langlais B, Reckhow DA and Brink DR (Eds) (1991). Ozone in Water Treatment. Lewis Publishers, Chelsea, Michigan, USA.

17. Mork, D. D. (1993). Removing sulfide with ozone. Water Contamination \& Purification. 34-37.

18. Mustafa, M. G. (1990). Biochemical basis of ozone toxicity. Free Radical Biology and Medicine, 9, 245-265.

19. Naitoh, S. (1991). Effect of ozone treatment to fruits and vegetables. AICH Food Res. Insti. Ann. Rep., 32:138-151.

20. Naitoh S, Sawada Y, Yamaguchi N. 1989. Studies on utilization of ozone in food preservation: Effect of ozone treatment on storage of packaged “Namamen," Japanese raw noodle. J AntibactAntifung Agents, 17:517-526.

21. Oehlschlaeger, H. F. (1978). Reactions of ozone with organic compounds. In R. G. Rice, \& J. A. Cotruvo (Eds.), Ozone/chlorine dioxide oxidation products of organic material (pp. 20-37). Cleveland: Ozone Press International.

22. Patil, S., Torres, B., Tiwari, B. K., Wijngaard, H. H., Bourke, P., Cullen, P. J. and Valdramidis, V. P. 2010. Safety and quality assessment during the ozonation of cloudy apple juice. Journal of Food Science, 75(7): 437-443.

23. PubChem. 2015. National Center for Biotechnology Information. PubChem Compound Database; CID=24823. Downloaded from https://pubchem. ncbi.nlm.nih.gov/compound/24823 on 9/2/2015.

24. Restaino L, Frampton EW, Hemphil JB, Palnikar P. 1995. Efficacy of ozonated water against various food-related microorganisms. Appl Environ Microbiol 61:3471-3475.

25. Rice, R.G., 1986. Application of ozone in water and waste water treatment. In: Rice, R.G., Browning, M.J. (Eds.), Analytical Aspects of Ozone Treatment of Water and Waste Water. Syracuse, The institute, New York, pp. 7-26.

26. Rice, R. G., Robson, C. M., Miller, G. W., \& Hill, A. G. (1981). Uses of ozone in drinking water treatment. Journal of the American Water Works Association, 73(1), 44-57.

27. Shigezo Naito \& Hirofumi Takahara (2006) Ozone Contribution in Food Industry in Japan, Ozone: Science \& Engineering, 28:6, 425-429.

28. Sofos, J. N., Busta, F. F. (1991) Chemical food preservatives. In: Principles and Practice of Disinfection, Preservation and Sterilization (2nd Edition) (Ed: Russell, A. D., Hugo, W. B. and Aycliffe, G. A. J.) Blackwell Scientific, Oxford. Pp 351-397.

29. Sykes G. 1965. Disinfection and sterilization, 2nd ed. London: E. \& F.N. Spon., Ltd.

30. Tapp, C. and Rice, R. G. 2012. Generation and control of ozone. In C. O'Donnell, B. K. Tiwari, P. J. Cullen, and R. G. Rice (Eds.), Ozone in Food Processing. Oxford, UK: Wiley-Blackwell. 312 p. 
31. WCBBC. Workers' Compensation Board of British Columbia. 2006. Library and Archives Canada Cataloguing in Publication Data. Ozone safe work practices: WCBBC.

32. WHO. World Health Organization. 2006. Air quality guidelines for particulate matter, ozone, nitrogen dioxide and sulfur dioxide: global update 2005. Geneva: World Health Organization, 1-22. Downloaded from http://whqlibdoc.who.int/hq/2006/ WHO_SDE_PHE_OEH_06.02_eng.pdf?ua=1 on 9/2/2105.

33. Zeynep B. Guzel-Seydim, Annel K. Greene, A. C. Seydim (2004) Use of ozone in the food industry. Lebensm.-Wiss. u.-Technol. 37: $453-460$. 